\title{
Aspects of Technology Developments of Lithium and Lithium-ion Batteries for Vehicle Applications in National R\&D Projects of Japan
}

\section{Kuniaki Tatsumi}

National Institute of Advanced Industrial Science and Technology,tatsumi-kuniaki@aist.go.jp

\begin{abstract}
Trends of technology developments of lithium and lithium-ion rechargeable batteries for hybrid electric vehicles (HEVS), plug-in HEVS (PHEVS), and battery electric vehicles (BEVs) in national R\&D projects of Japan are reviewed. In addition, roadmap of current status for $R \& D$ for improving specific power and specific energy of the batteries in national project in Japan are overviewed.
\end{abstract}

\section{Keywords}

national R\&D project, electric vehicle, lithium and lithium-ion battery, hybrid electric vehicle, battery EV

\section{INTRODUCTION}

Energy and environmental issues of vehicles have become more and more serious from the viewpoint of resource security of petroleum and global warming by emission of greenhouse effect gas, such as $\mathrm{CO}_{2}$. Electric drive is one of the most effective measuresto overcome the energy issues of vehicles, because energy efficiency of electric drive is generally much higher than that of internal combustion engine. In addition, energy resources for electricity are not only petroleum but also various energy resources, such as coal, nuclear, and renewable energies (hydro-power, wind-power, and photovoltaic). In the countries of low fossil energy usage for electricity generation, electric drive reduces $\mathrm{CO}_{2}$ emission. Electric vehicles (EVs), however, have faced several high barriersto be solved for commercialization. In particular, rechargeable battery is still one of the most important key issues for EV commercialization; energy density and calendar life are not enough to realize electric vehicles comparable to gasoline engine vehicles. Furthermore, cost of rechargeable batteries is quite expensive.

In recent years, the interest in hybrid electric vehicles (HEVs) and plug-in HEVs (PHEVs) has been rapidly increasing. In these applications, except cost issue, requirements for rechargeable batteries, Ni metal hydride batteries and Li-ion batteries, are not necessarily too high to makeHEVs and PHEVscommercialize. However, several of the requirements of rechargeable batteries even for HEVs and PHEVs are quite different to those for portable electronic devices; in particular, high specific power $(>1-2 \mathrm{~kW} / \mathrm{kg})$ and long calendar life ( $>10$ or 15 years) are very important requirements for HEVs and PHEVs. In this paper, lithium and lithium-ion battery technology for HEVs, PHEVs and battery EVs (BEVs) in national R\&D projects of Japan are reviewed.

2. R\&D OF LARGE-SCALED LITHIUM AND LITHIUM-ION BATTERIES (LIBES PROJECT IN FY1992-2001)

As a part of the New Sunshine Program promoted by

Table 1 AIST, MITI (New Sunshine program) - NEDO project (FY1992-2001) "Dispersed-type Battery Energy Storage technology"

\begin{tabular}{|l|l|c|c|c|c|c|}
\hline & & \multicolumn{2}{|c|}{ Stationary-type } & \multicolumn{2}{c|}{ Vehicle-use } \\
\hline & & Target & Result & Target & Result \\
\hline Energy in module level & $(\mathrm{kWh})$ & 2 & $2.3-2.5$ & 3 & $3.8-4.1$ \\
\hline Energy density & $(\mathrm{Wh} / \mathrm{kg})$ & 120 & $122-128$ & 150 & $150-155$ \\
\hline & $(\mathrm{Wh} / \mathrm{L})$ & 240 & $245-255$ & 300 & $252-323$ \\
\hline Power density & $(\mathrm{W} / \mathrm{kg})$ & - & & 400 & $438-489$ \\
\hline Cycling efficiency & $(\%)$ & 90 & $96-98$ & 85 & $96-97$ \\
\hline Cycle life & $(\mathrm{cycles})$ & 3,500 & $>3,000$ & & 1,000 & $>1,000$ \\
\hline
\end{tabular}


Table 2 AIST, MITI (New Sunshine program) - NEDOproject (FY1992-2001) “Dispersed-type Battery Energy Storage technology"

\begin{tabular}{|l|l|c|c|c|c|}
\hline & & Target & Ni-based & Composite & Mn-based \\
\hline Energy density & $(\mathrm{Wh} / \mathrm{kg})$ & 70 & 70.7 & 72 & 75 \\
\hline Power density & $(\mathrm{kW} / \mathrm{kg})$ & 1.8 & $1.9-2.1$ & $2.2-2.5$ & 2.3 \\
\hline Charge-discharge energy efficiency & $(\%)$ & 96 & 93.4 & 91.4 & - \\
\hline Life & $($ year $)$ & 15 & 16 & $>15$ & $>15$ \\
\hline Cost & $(\mathrm{JPY} 1,000 / \mathrm{kWh})$ & 50 & 44.0 & 39.8 & 38.0 \\
\hline
\end{tabular}

METI, a 10 years R\&D project for developing largescale lithium rechargeable batteries for stationary and BEVs applications was commenced in FY 1992 and completed in FY 2001 with various successful results accomplishing the project targets. The $3 \mathrm{kWh}$ class lithium-ion rechargeable batteries for an BEV application developed by the Lithium Battery Energy Storage Technology Research Association (LIBES) possessedvarious high performance in specific energy (>150 Wh/kg), cyclic energy efficiency (>96\%), and specific power $(>400 \mathrm{~W} / \mathrm{kg})$, as shown in Table 1 .

At the early period of the LIBES project, R\&D on both of lithium and lithium-ion batteries was promoted. In this period, it was not known whether lithiumion batteries are a feasible for BEV applications, because a lithium-ion battery was just commercialized for mobile electronic devices in 1991. In addition, metallic lithium rechargeable battery also had severe problems of dendritic growth of lithium during charge which causes short cycle life and safety issues. The LIBES project has successfully demonstrated that lithium-ion batteries are feasible battery system for BEV applications, though difficulties of metallic lithium rechargeable cells for commercialization remained unsolved. Specific energy of $150 \mathrm{Wh} / \mathrm{kg}$ even in the 3 $\mathrm{kWh}$ module level is still one of the highest specific energy of the battery modules for vehicle applications, and such high specific energy was demonstrated with graphite negative electrodes and positive electrode materials consisting of $\mathrm{Li}(\mathrm{NiCo}) \mathrm{O}_{2}$ or $\mathrm{LiMn}_{2} \mathrm{O}_{4}$.

\section{R\&D OF LITHIUM-ION BATTERIES FOR FUEL CELL VEHICLES AND HEVS (IN FY2002-2006)}

From FY2002, a new R\&D project (5 years project) on large-scaled lithium rechargeable batteries has been commenced as a part of the "PEFC/Hydrogen Energy Utilization Program". The aim of this project is to develop Li-ion rechargeable batteries with high specific power for fuel cell vehicles (FCVs) and HEVs. Although the LIBES project developed high specific energy batteries, specific power of the battery system was less than $500 \mathrm{~W} / \mathrm{kg}$. Ni-MH batteries in Toyota Prius were announced to be higher than $1.3 \mathrm{~kW} / \mathrm{kg}$. In HEV system, capacity of batteries is relatively small in comparison with BEV system, 1 to $2 \mathrm{kWh}$. Therefore, power density is more important specification than energy density in HEV applications; battery system output power of several tens $\mathrm{kW}$ for vehicle acceleration. However, organic electrolytes in lithiumion cells show relatively low ionic conductivity; ionic conductivity of organic electrolyte for lithium-ion cells is approximately $1 / 100$ of that of water medium electrolytes. Poor ionic conductivity generally leads to low power of battery system. Therefore, power density achieved by lithium-ion battery system was a very important issue for judging which battery system is suitable for HEV applications.

As shown in Table 2, this R\&D project has also successfully completed with showing high power lithiumion battery possible. The developed $3 \mathrm{kWh}$ lithiumion battery module possessed specific power higher than $2 \mathrm{~kW} / \mathrm{kg}$, while specific energy of the module is approximately half of those developed in the LIBES project. Specific power of $3 \mathrm{kWh}$ Li-ion battery modules more than $2 \mathrm{~kW} / \mathrm{kg}$ was demonstrated with hard carbon negative electrodes and positive electrode materials consisting of $\mathrm{Li}(\mathrm{NiCo}) \mathrm{O}_{2}$ or $\mathrm{LiMn}_{2} \mathrm{O}_{4}$.

\section{R\&D OF LITHIUM-ION BATTERIES FOR FUEL CELL VEHICLES AND HEVS (LI-EAD PROJECT IN FY2007-2011)}

In 2006, the Japanese government announced "National Energy Strategy", and in this strategy, it is stated to suppress petroleum dependency of the vehicle sector from $100 \%$ to $80 \%$ in 2030 . This reduction of petroleum dependency is significantly important from the viewpoint of energy security and the global warming by greenhouse effect gases. Furthermore, this issue has urgently become more and more serious with spreading vehicle usage in the world. Also in Japan, automotive manufacturers have commercial- 
Table 3 Direction and milestone of R\&D for the batteries for vehicles

\begin{tabular}{|c|c|c|c|c|c|c|}
\hline & & Current & $\begin{array}{c}\text { Improved } \\
(2010)\end{array}$ & $\begin{array}{c}\text { Advanced } \\
(2015)\end{array}$ & & $\begin{array}{c}\text { Innovative } \\
(2030)\end{array}$ \\
\hline \multicolumn{2}{|c|}{$\begin{array}{l}\text { Vehicles } \\
\text { Expected to be realized }\end{array}$} & $\begin{array}{c}\text { Small-sized EVs } \\
\text { HVs }\end{array}$ & $\begin{array}{l}\text { Business use } \\
\text { commuter EVs } \\
\text { More Efficient } \\
\text { HVs }\end{array}$ & $\begin{array}{c}\text { Commuter EVs } \\
\text { Fuel Cell Vehicles } \\
\text { Plug-in HVs } \\
(20 \mathrm{~km} \mathrm{EV})\end{array}$ & $\begin{array}{c}\text { Plug-in HVs } \\
(60 \mathrm{~km} \mathrm{EV})\end{array}$ & $\begin{array}{c}\text { Standard-sized } \\
\text { EVs }\end{array}$ \\
\hline Performance & & 1 & 1 & 1.5 times & 3 times & 7 times \\
\hline \multirow[t]{2}{*}{$\mathrm{BEV}$} & Specific energy $[\mathrm{Wh} / \mathrm{kg}]$ & 100 & 100 & 150 & & 700 \\
\hline & Specific power $[\mathrm{W} / \mathrm{kg}]$ & 400 & 1000 & 1200 & & 1000 \\
\hline \multirow[t]{2}{*}{$\mathrm{HEV}$} & Specific energy $[\mathrm{Wh} / \mathrm{kg}]$ & 70 & 70 & 100 & 200 & \\
\hline & Specific power $[\mathrm{W} / \mathrm{kg}]$ & 1900 & 2000 & 2000 & 2500 & \\
\hline \multicolumn{2}{|l|}{ Cost } & 1 & $1 / 2$ & $1 / 7$ & $1 / 10$ & $1 / 40$ \\
\hline \multicolumn{2}{|c|}{ Leading role for development } & Industry initiative & Industry initiative & \multicolumn{2}{|c|}{$\begin{array}{l}\text { Industry-government-academia } \\
\text { collaboration }\end{array}$} & $\begin{array}{l}\text { Universities } \\
\text { and Research } \\
\text { institutions }\end{array}$ \\
\hline
\end{tabular}

Note: Relative comparison using gravimetric energy density

ized BEVs even in 2001. However, those BEVs were still too expensive to be popular in the automotive market,and the driving ranges were short, less than half of gasoline vehicles in addition to long refueling, recharging time. Therefore, BEVs have not succeeded to find a market in Japan. On the other hand, HEVs with Ni-MH battery have succeeded to catch a certain share in the market. Share of HEVs in the passenger car market in Japan has been more than $10 \%$ since last May. Moreover, plug-in HEVs (PHEVs) that can be plugged and charged as a bifuelvehicle driven by petroleum and electricity have attracted much attention.

In the METI report in 2006, targets of the batteries are mainly estimated by requirements for the vehicles expected to be realized (Table 3). Since FY2007, METI and NEDO have launched a battery development project, named as "Li-ion and Excellently Advanced battery Development (Li-EAD)" project, for next generation vehicles, such as PHEVs and BEVs. Concerning PHEV having $20 \mathrm{~km}$ EV driving range, advanced Li-ion battery probably make it possible. However, for PHEV having $60 \mathrm{~km} \mathrm{EV} \mathrm{driving} \mathrm{range,} \mathrm{it} \mathrm{is} \mathrm{esti-}$ mated that Li-ion battery having specific energy more than $200 \mathrm{Wh} / \mathrm{kg}$ in a battery pack lever is required. Specific energy of $200 \mathrm{Wh} / \mathrm{kg}$ in a battery pack level is a quite high challenge even in Li-Ion system, because $150 \mathrm{Wh} / \mathrm{kg}$ demonstrated in the LIBES project is thought to be an upper limit of battery module with lithium-ion cells with graphite or hard carbon negative electrodes and $\mathrm{Li}(\mathrm{NiCo}) \mathrm{O}_{2}$ or $\mathrm{LiMn}_{2} \mathrm{O}_{4}$ positive electrodes. This means lithium-ion system with other new electrode materials should be developed. Hence, new electrode materials of high capacity and other component materials contributing to realize highly reliable battery system have been studied in the Li-EAD. For negative electrodes, silicon is one of the most promising candidates. However, for positive electrodes, there are few candidates having much higher capacity; $\mathrm{Li}_{2} \mathrm{MnO}_{3}-\mathrm{LiMO}_{2}(M=\mathrm{Co}, \mathrm{Ni}, \mathrm{Fe}$ etc. $)$ system may make the lithium-ion cell of specific energy higher than $200 \mathrm{Wh} / \mathrm{kg}$ possible.

Moreover, standard-size BEVs require 7 times improvement in performance, and Li-ion system cannot meet with this targets. Post Li-ion system, such as metallic lithium rechargeable cell or metal-air rechargeable batteries, should be developed for standard-size BEVs.

\section{CONCLUSION}

Improvements of energy density and power density are required for vehicle applications. Lithium and lithium-ion rechargeable batteries are expected to be the power sources for next-generation vehicles. Moreover, further improvement of capacity pushes the R\&D of the new electrode materials. For negative electrode materials, carbons, alloys, and metallic lithium have attracted much attention. For positive electrode materials, amount of Co should be reduced. Spinel Mn oxides with higher safety, Ni-Mn layered oxides, and Ni-Mn-Co layered oxides have been intensively studied. In addition, Ni-Co oxides are also interesting in the viewpoint of higher capacity and higher power density. For positive electrode materials of the next generation battery, sulfur and air-electrode are also good candidate. However, both systems still have 
drawbacks of reversibility and rate properties, and so on to be solved for commercialization.

(Received December 15, 2010) 